\title{
The Litigation Aspects in Solving Banking Disputes in the Sharia
} Sector

\author{
Hashim Sofyan Lahilote *1 Wulanmas A.P.G. Frederik ${ }^{2} \quad$ J. Ronald Mawuntu ${ }^{2}$ \\ Abdurrahman Konoras ${ }^{3}$ \\ 1.PhD Student, Departement of Law Studies, Postgraduate Program, Sam Ratulangi University, Manado, \\ Sulawesi Utara, Indonesia \\ 2.Profesor Departement of Law Studies, Postgraduate Program, Sam Ratulangi University, Manado, Sulawesi \\ Utara, Indonesia \\ 3.Departement of Law Studies, Postgraduate Program, Sam Ratulangi University, Manado, Sulawesi Utara, \\ Indonesia
}

\begin{abstract}
The expansion of authority, duties, and functions of the Religious Judicature, has led the authority of the Religious Judicature are not solely in charge of the conventional fields, such as marriage, divorce, inheritance, grant (hibah), charity (zakah), and others, but the authority in the field of Islamic economics, particularly Islamic banking as well. Disputes between Islamic Banking and its customers are mostly caused by customers' default towards agreement provision, the Financing Agreement to the detriment of the Islamic Bank. The default litigant from an offense under the substance of Financing Agreement that can be through by litigation in the Religious Judicature or non-litigation as through Basyarnas. This research is about the competence of Religious Judicature in resolving disputes Islamic Banking as a normative legal research using several approaches including legislation approaches. The research found that the settlement of Islamic banking dispute in Indonesia has external and internal constraints. External constraints, such as lack of harmonization among legislation, it even contradicts one another. Then, internal constraints such as the lack of the Religious Judicature judges understanding on various aspects of Islamic Banking, because those are relatively new, while the judges mostly experienced in resolving divorce, inheritance, grants (hibah), endowments (waqaf), and so forth. The results of this study recommend the need for harmonization and synchronization between legislation related to the drafting, moreover, a new procedural law of Religion Judicature in lieu of procedural law based $\mathrm{HIR} / \mathrm{RBg}$ and increasing the ability of the Judges in reforming Islamic law through the Judge's decision are necessary.
\end{abstract}

Keywords: Religious Judicature, Islamic Banking, Authority.

DOI: 10.7176/PPAR/9-8-07

Publication date: August $31^{\text {st }} 2019$

\section{A. Introduction}

Religious Judicature has been long known, even its presence and influence gained attention from the Dutch government. The Decree of the Netherland King (Koninklijk Besluit) on January $19^{\text {th }}, 1882$ No. 22, State Gazette 1882-152) had changed the composition and status of Religious Judicature. The authority of Religious Judicature called "pressterraacf" remained in the areas of marriage and inheritance law, and the recognition and affirmation of the existence of Religious Judicature and Islamic law as a basis. ${ }^{1}$

HA Mukti Arto stated that there is no other court which is in charge and responsible for the enforcement of Islamic sharia law beside the court within the Religious Judicature in Indonesia. Islamic sharia law has already transformed into legislation and some have not. In the study of law, Islamic law is categorized into applicable written law or positive law (ius constitutum) applies. ${ }^{2}$

One of the Religious Judicature authority, according to Law Number 50 of 2009 is set on the elucidation of Article 49, "Religious Judicature duty and authority are to examine, decide and resolve cases at the first level among people who are Muslims in the areas of:
a. Marriage;
b. Inheritance;
c. Grant (hibah);
d. Endowments (waqaf);
e. zakah;
f. Infaq;
g. Sadaqah; and

\footnotetext{
1 " Sejarah Peradilan Agama ", Posted on https://badilag.mahkamahagung.go.id/ history / profile-directorate-Badilag-I, accessed on $26^{\text {th }}$ April 2018

${ }^{2}$ H.A. Mukti Arto, Penemuan Hukum Islam Demi Mewujudkan Keadilan, $1^{\text {st }}$ Book, Pustaka Pelajar, Yogyakarta, 2017, p. 19
} 
h. Islamic Economics. "1

Article 49 which regulates the duties and authority of the Religious Judicature in examining, deciding and resolving cases at the first level among the Muslims, especially in the field of Islamic Economics. Article 49 point $\mathrm{h}$ explains that the "Islamic Economics" is an action or business activities are carried out according to the following Islamic principles:

a. Islamic Bank;

b. Islamic Microfinance Institutions;

c. Islamic Insurance;

d. Islamic Reinsurance;

e. Islamic Bonds or Islamic Medium Term Securities;

f. Islamic securities;

g. Islamic finance;

h. Islamic pawnshop; and

i. Islamic Business. "2

One area of Islamic Economics is Islamic banking area that is different from conventional banking. The first is the legal basis. Conventional banks regulated in Act Number 7 of 1992 on Banking, that is not as Islamic banking, is based on the principle of profit sharing,

Article 6 point m of Act No. 7 of 1992 on Banking, stated that " Commercial Bank business provides financing for customers based on the principle of profit sharing in accordance with the provisions set by Government Regulation." ${ }^{3}$ Government regulations here mean Government Regulation No. 72 of 1992 on Banking based upon the Profit Sharing Principle, ${ }^{4}$ of Act No. 7 of 1992 on Banking.

The amendment of Act Number 7 of 1992 on Banking by Act No. 10 of 1998, was already starting to mention Islamic Principle, as stated and formulated in Article 1 paragraph 13, that " Syariah Principles are rules of agreement based on Islamic Law between Bank and other parties for depositing fund and/or financing business activities, or other activities which are stated as in accordance with Syariah Principles. "5

Based on Act No. 21 of 2008 on Islamic Banking, the old provisions regulated by Act No. 7 of 1992 as amended by Act No. 10 of 1998, made the adjustment in accordance with Article 69 of Act No. 21 of 2008, "At the time this Act is applied, all provisions of the Islamic Banking regulated in Law Number 7 of 1992 concerning Banking (State Gazette of the Republic of Indonesia of 1992 Number 31, Supplement to the State Gazette of the Republic of Indonesia Number 3472) as amended by Act No. 10 of 1998 (Official Gazette of the Republic of Indonesia of 1998 Number 182, Supplement to the State Gazette of the Republic of Indonesia Number 3790) and its implementing regulations shall remain valid to the contrary in this Act. "6

Islamic Banking is one of the duties and authorities of the Religious Judicature in resolving cases or disputes. The settlement of Islamic Banking dispute is set in Chapter IX of Act No. 21 of 2008, but the regulation contains inconsistent provisions and gives opportunities for choosing law (choice of law) and forum (choice of forum) in dispute settlement rather than through Religious Judicature.

According to Salim HS and Erlies Septiana Nurbani, ${ }^{7}$ philosophically, dispute settlement is an attempt to restore the relationship of the legal dispute parties. Thus, the parties have a good relationship, both social and law.

The efforts are closely related to the manner or the dispute settlement mechanism. Rachmadi Usman explained that the dispute can be done through two processes. The oldest dispute resolution process through litigation in the courts, and then it is developed into the process of settling disputes through cooperation (cooperative) out of the court. ${ }^{8}$

The completion of civil disputes such as the dispute within the scope of Islamic Banking, are not solely be resolved by courts (litigation) but outside the court (non-litigation) as well. Act Number 48 of 2009 on Judicial Power, specifies in Article 58 that " dispute resolution attempt of the civil code can be done outside the State Court through arbitration or alternative dispute resolution." 9

According to Article 58 of Act Number 48 of 2009 on Judicial Power, dispute settlement can be reached through arbitration and alternative dispute settlement. It is also in line with the provisions of Act No. 30 of 1999 on Arbitration and Alternative Dispute Settlement. There are three (3) ways of settlement. The first is the settlement of disputes through the courts. The second, disputes settlement through arbitration and the last is by alternative

\footnotetext{
${ }^{1}$ See Act No. 50 of 2009 on the Second Amendment to Law Number 7 of 1989 on the Religious Courts (Article 49)

${ }^{2}$ See Act No. 50 of 2009 on the Second Amendment to Law Number 7 of 1989 on the Religious Courts (Explanation of Article 49 point h)

${ }^{3}$ See Act No. 7 of 1992 on Banking (Article 6 point a)

${ }^{4}$ See Government Regulation No. 72 of 1992 on Bank based on Principles of Sharing

${ }^{5}$ See Act No. 10 of 1998 on the Amendment of Law Number 7 of 1992 on Banking (Article 1 Point 13)

${ }^{6}$ See Act No. 21 of 2008 on Sharia Banking (Article 69)

${ }^{7}$ Salim HS dan Erlies Septiana Nurbani, Penerapan Teori Hukum Pada Penelitian Tesis dan Disertasi, Buku Kesatu, RajaGrafindo Persada, Jakarta, 2014, p. 135

${ }^{8}$ Rachmadi Usman, Pilihan Penyelesaian Sengketa di Luar Pengadilan, Citra Aditya Bakti, Bandung, 2013, p. 5

${ }^{9}$ See Act No. 48 of 2009 on Judicial Power (Article 58)
} 
dispute settlement.

Those dispute settlements are in the state courts, like the General Court and Religious Court. According to Huala Adolf, ${ }^{1}$ The national court is the proper forum to resolve disputes. The national court is the local court where the dispute is from. Developing countries generally hold that authority adjudicate disputes in economics (including investments) that are in the national courts of the country.

The settlement of Islamic Banking disputes based upon the Article 55 of Act No. 21 of 2008 on Islamic Banking, is precisely by the judiciary not only the authority of the Religious Judicature but also of General Jurisdiction. Furthermore, the argument that unprepared and inexperienced of the Religious Judicature compared to the General Court, like the District Court, in dealing with disputes or cases of Islamic Banking, also should be observed.

Another issue in Islamic banking dispute settlement is the existence of National Sharia Arbitration Board (Basyarnas) as a legal institution in the Islamic business activities, for instance, Islamic Banking faces the execution process of Basyarnas decision. These problems indicate a lack of confidence in the ability Basyarnas to perform the execution, because it is from the Supreme Court Circular Letter No. 08 of 2008 on Execution Decision Arbitration Board that has the authority to execute in accordance with point 3 which states "Decisions of Sharia Arbitration Board is final and have permanent legal force and binding on the parties (Article 60 of Act No. 30 of 1999), therefore, the parties should implement the decision of the Syariah Arbitration Board voluntarily. "2

The Supreme Court later change its mind by issuing the Supreme Court Circular (SEMA) No. 08 of 2010 on Affirmation Not Applicability of the Supreme Court Circular Letter No. 08 of 2008 on Sharia Arbitration Decision Execution, ${ }^{3}$ because it refers to the provisions of Article 59 paragraph (3) of Act Number 48 of 2009 on Judicial Power, which states "In the event that the parties do not implement the sharia arbitration decision voluntary, the decision is implemented based on the command of the chair of the District Court as the request of either the disputing party. "4

This problem shows the inability of the Chairman of the Religious Court to do Verdict Execution voluntarily, so it must ask for help from the Chairman of the District Court to do so. The author found that in the Marriage Act by Act No. 1 of 1974 on Marriage, concerning divorce, in Article 36 paragraph (1) of Government Regulation No. 9 of 1975 on the implementation of Act No. 1 of 1974 on Marriage, stated that " Religion Court judgment no later than 7 (seven) days after the divorce was decided, delivered a decision which has had binding legal force to the District Court to be confirmed. "5

The provisions of Article 36 paragraph (1) on "Confirmation" explains that confirmation by the District Court towards the Religious Court verdict is only when it has had permanent legal force. In other words, the confirmation has not been made if a decision of courts is appealed. The inauguration is administrative. District Court did not conduct re-examination that such decision.

Regarding the provision and explanation above, it is clear that the legislation put the position of the Religious Court is not aligned with the District Court, because of the independence of the Religious Judicature in their divorce case still needs to be confirmed to the District Court. It also happens in the execution of Basyarnas decision that still require the command from the Chairman of the District Court as referred to the Article 59 paragraph (3) of Act Number 48 of 2009 on Judicial Power.

\section{B. Framework.}

\section{B.1. Theory of Justice}

The theoretical basis of this research is based on the theory of law (legal theory). Salim HS formulated that legal theory is a theory that examines and analyzes the law of the normative dimension, empirical, and the binding effect of law. ${ }^{6}$

Etymologically, the term "justice" is derived from an Arabic term, "fair" (al-'adl) which means not unbiased. ${ }^{7}$ Law Dictionary defines the word fair as not favoring one of the parties; honest; favor of the truth related to the law. ${ }^{8}$

Justice has been one subject of conversation and debate that did not go over. The essence of justice is still researched by philosophers and scholars until now. Abdul Manan, ${ }^{9}$ explains that some legal experts argued that a good law is a law which could satisfy the justice that always evolving to follow the value of human justice. Public

\footnotetext{
${ }^{1}$ Huala Adolf, Hukum Penyelesaian Sengketa Penanaman Modal, Kani Media, Bandung, 2011, p. 4

${ }^{2}$ See SEMA No. 08 of 2008 on the execution of Sharia Arbitration Board (Item 3)

${ }^{3}$ See SEMA No. 08 of 2010 on the assertion Not Applicability of SEMA No. 08 of 2008 on Sharia Execution Arbitration Decision (third paragraph)

${ }^{4}$ See Act No. 48 of 2009 on Judicial Power (Article 59 paragraph (3)

${ }^{5}$ See Government Regulation No. 9 of 1975 on the implementation of Law No. 1 of 1974 on Marriage (Article 36 paragraph (1)

${ }^{6}$ Salim HS, Perkembangan Teori Dalam Ilmu Hukum, RajaGrafindo Persada, Jakarta, 2010, p. 55

${ }^{7}$ Anonymous, Ensiklopedia Hukum Islam, PT. Ichtiar Baru, Jakarta, 1996, p. 25

${ }^{8}$ Charlie Rudyat, Kamus Hukum, No Publisher, No Years, p. 14

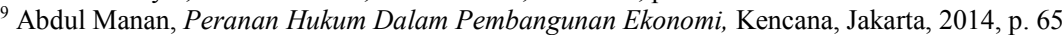


legal awareness will arise if there is a match between the justice in the community and the justice that is to be achieved by applicable law.

Aristoteles, ${ }^{1}$ classified justice into three parts: Commutative Justice, Distributive Justice, and Vindicative Justice. Commutative Justice is the treatment to someone without looking at their services, everyone gets their rights. Distributive justice is the treatment to a person in accordance with the service that has been made, each person gets capacity based on their own potential. Vindicative justice is the treatment to a person based on their behavior as the crime committed.

\section{B.1.2. Authorities theory.}

Authorities terms and words are derived from the word "Authority" which means: the right and the power to act. ${ }^{2}$ The authority as in English can be equated with the term "Bevoegheid" in Dutch. ${ }^{3}$ From a theoretical perspective, the theory of authority is derived from the English translation, the Authority of Theory, whereas the term used in the Dutch language, namely Theory van het gezag, as well as in German, namely Theorie der autoritit. The theory of authority comes from two words, the theory, and authority.

Authority is defined as Right to exercise power; to implement and enforce the laws; to exact obedience; to command; to judge. Control over; jurisdiction, Often Synonymous with powers. ${ }^{4}$ Salim HS and Erlies Septiana Nurbani described the authority of formula Henry Campbell Black, that the authority is not only interpreted as a right to carry out the exercise of power, but the authority also interpreted as:

1. To implement and enforce the law;

2. Obedience is certain;

3. Command;

4. Decision;

5. Supervision;

6. Jurisdiction; and/or

7. Power. $^{5}$

According to HD. Stout, authority is a definition that comes from government organization law, which can be explained as a whole of the rules relating to the acquisition and the use of government authority by the subject of public law in a public law relationship. ${ }^{6}$ Meanwhile, Philip M. Hadjon described the term of authority in the Dutch language, Bevoegheid, is used in the concept of private and public law, whereas the authority is always used in the concept of public law. ${ }^{7}$

Bagir Manan explained that authority in legal language is the same as the power (macht). Power only describes the rights to do or not do. In law, the authority means rights and obligations (rechten en plichten). Regarding regional autonomy, the right implies the power to govern properly. Vertical means the power to apply the whole of government. ${ }^{8}$

Obtaining a legal source of authority is the focal point of the source of the law itself. Philip M. Hadjon interpreted that legal sources as what lead to rules that have coercive poweris rule that results in the penalty if it is violated. ${ }^{9}$

According to Sudikno Mertokusumo, essentially what is meant by a source of law is where people can determine or dig law. ${ }^{10}$ The main source of law became the basis of an authorization, is determined based on the legislation as the legal basis of the authority itself, a source of primary law in Indonesia is legislation.

Act Number 12 of 2011 on the Establishment Regulation Legislation, formulated in Article 1 paragraph 2, that " Legislation, formulated in Article 1 paragraph 2, that" Legislation is written regulation containing legal norms generally binding and formed or defined by state agencies or competent authorities through the procedure set in Legislation. "11

In Article 7 paragraph (1) of Act Number 12 of 2011 on the Establishment Regulation Legislation, stated that the "type and hierarchy of Regulation Legislation" consist of:

a. The 1945 Constitution of the Republic of Indonesia;

b. People's Consultative Assembly Decree;

\footnotetext{
1 “Teori Keadilan”, published on http://rahmanjambi43.wordpress.com/2015/02/06/ paper-theory-justice, Accessed on $26^{\text {th }}$ April 2018

2 "Wewenang", published in: kbbi.web.id. Accessed on $26^{\text {th }}$ April 2018

${ }^{3}$ Nur Basuki Minarno, Penyalahgunaan wewenang Dalam Pengelolaan Keuangan Daerah Yang Berimplikasi Tindak Pidana Korupsi, LaksBang Mediatama, Yogyakarta,2011, p. 65

${ }^{4}$ Henry Campbell Black, Black's Law Dictionary, West Publishing Co, St. Paul, 1979, p. 121

${ }^{5}$ Salim HS dan Erlies Septiana Nurbani, Penerapan Teori Hukum Pada Penelitian Tesis dan Disertasi, Buku Kesatu, Op Cit, p. 185

${ }^{6}$ Juniarso Ridwan dan Achmad Sodik Sudrajat, Hukum Administrasi Negara dan Kebijakan Pelayanan Publik, Nuansa, Bandung, 2010, p. 136

${ }^{7}$ Nur Basuki Minarno, Op Cit, p. 65

${ }^{8}$ Ridwan HR, Hukum Administrasi Negara, RajaGrafindo Persada, Jakarta, 2006, p. 102

${ }^{9}$ Philip M. Hadjon, Pengantar Hukum Administrasi Indonesia, Gadjah Mada University Press, Yogyakarta, 1993, p. 52

${ }^{10}$ Sudikno Mertokusumo, Mengenal Hukum. Suatu Pengantar, Liberty, Yogyakarta, 2005, p. 82

${ }^{11}$ See Act No. 12 of 2011 on the Establishment Regulation Legislation (Article 1 paragraph 2)
} 
c. Law / Government Regulation in Lieu of Law;

d. Government regulations;

e. Presidential decree;

f. Provincial Regulation; and

g. Regulation of the Regency / City. "1

Sources of Religious Judicature authority associated with the provision of Article 7 paragraph (1) of Act Number 12 of 2011 on the Establishment Regulation Legislation, can be found in the 1945 Constitution of the Republic of Indonesia and the Legislation.

Article 24 of the 1945 Constitution of the Republic of Indonesia, states as follows:

(1) The judicial power shall be independent and shall possess the power to organize the judicature in order to enforce law and justice.

(2) The judicial power shall be implemented by a Supreme Court and judicial bodies underneath it in the form of public courts, religious affairs courts, military tribunals, and state administrative courts, and by a Constitutional Court.

(3) Other institutions whose functions have a relation with the judicial powers shall be regulated by law.

The source of Religion Court legal authority is also found in the legislation, such as Article 18 of Act Number 48 of 2009 on Judicial Power, ${ }^{3}$ it is similar to the Article 24 paragraph (1) and (2) of the 1945Constitution of the Republic of Indonesia.

The source of the Religious Judicature authority in resolving disputes and Islamic Banking, set in the legislation, namely Article 55 paragraph (1) of Act Number 21 of 2008 on Islamic Banking, which states that "the Settlement of Islamic Banking is done by the court within the Religious Court. "4

\section{B.1.3. Dispute settlement theory.}

In terminology, the term "Disputes" is often interpreted as the same as the term "Conflict" However, there are also experts who differentiate between a conflict and the dispute. First, the term conflict implies wider than the dispute because the conflict may include disputes latent and disagreements that have manifested. Second, the conflict refers to the disputes that it has or has not been identified or can be clearly identified. Third, the term conflict is more often found in the literature of the social sciences and politics. ${ }^{5}$

Theoretically, dispute settlement theory is a translation of foreign language terms, which is in English, in the Dutch, it is called theorie ven de beslachting van geschillen. According to Dean G. Pruit and Jeffrey Z. Rubin, the formulation that the dispute is the perception of the difference in interest (perceived divergence of interest) or a belief that the aspirations of the parties to the dispute are not achieved simultaneously. ${ }^{6}$

Dispute settlement itself is from the existence of a dispute. The dispute is a situation in which there are those who feel aggrieved by the other parties. Those who feel aggrieved express this dissatisfaction to the second party and if the party does not respond and satisfy the first party and showing the dissent, then it is named as the dispute. ${ }^{7}$

The concept of dispute settlement under Indonesian law is distinguished into two: judicial dispute settlement (litigation) and dispute settlement outside the court (non-litigation). Settlement of disputes through the courts can be regarded as a conventional dispute settlement way or model, which began to develop and apply. Suyud Margono explained, conventionally, the settlement of disputes are usually in the business world, such as in trade, banking, mining projects, oil and gas, energy, infrastructure, and so on that are done through litigation. In the process of litigation, the parties are opposite each other, in addition, settlement of disputes in litigation is a means of last way (ultimum remedium) if other alternative dispute settlements are failed. ${ }^{8}$

In Indonesia, it is known as litigation and non-litigation dispute settlement, which has been set in different Acts. Settlement of disputes through the Public Judicature is regulated by Act No. 49 of 2009 on the Second Amendment to Act No. 2 of 1986 on the General Court, which is defined in Article 1 paragraph 1 that "The courts are district courts and high courts in the public judicature. " 9

The settlement through the courts (litigation) can also be resolved through the Religious Judicature based upon Act No. 50 of 2009 on the Second Amendment to Law Number 7 of 1989 on Religious Judicature, which is in Article 1 paragraph 2 stated that "The court is the religious and high court of religion in Religious Judicature.

\footnotetext{
${ }^{1}$ See the 1945 Constitution of the Republic of Indonesia (Article 1 paragraph 2)

${ }^{2}$ See the 1945 Constitution of the Republic of Indonesia (Article 7 (1))

${ }^{3}$ See Act No. 48 of 2009 on Judicial Power (Article 18)

${ }^{4}$ See Act No. 21 of 2008 on Islamic Banking (Article 55 paragraph (1)

${ }^{5}$ Takdir Muhammad, Mediasi. Penyelesaian Sengketa Melalui Pendekatan Mufakat, RajaGrafindo Persada, Jakarta, 2011, p. 1-3

${ }^{6}$ Dean G. Pruitt and Jeffrey Z. Rubin, Konflik Sosial, Reader Student, Yogyakarta, 2004, p. 9-10

${ }^{7}$ Suyud Margono, ADR \& Arbitrase-Proses Pelembagaan dan Aspek Hukum, Ghalia Indonesia, Bogor, 2000, pp. 34

${ }^{8}$ Ibid, p. 12

${ }^{9}$ See Act No. 49 of 2009 on the Second Amendment to Law No. 2 o1986 on the General Court (Article 1 paragraph 1)f
} 
The settlement through outside the court is set in Act No. 30 of 1999 on Arbitration and Alternative Dispute Resolution, which broadly regulates arbitration and dispute settlement alternative.

\section{Research methods.}

C.1. Types of research

This research is a normative legal research by researching and using primary, secondary, and tertiary legal materials obtained from library research. This type of research is about the vagueness of the law (Vage Norm), the rules of the legislation of the subject matter are already existed but are unclear. ${ }^{2}$

The vagueness of the law in Article 55 which indicates the contradictory between Article 55 paragraph (1) of Act No. 21 of 2008 which stated competence of the Religious Court in resolving disputes of Islamic Banking through the General Court, because the principles of the Establishment Regulation Legislation mandated by Law Number 12 of 2011 on the Establishment Regulation legislation have less attention.

Article 5 of Act No. 12 of 2011 stated "The Legislation formulation should be based on the principle of good Establishment Legislation, which includes:
a. Clarity of purpose;
b. Institutional or forming proper authorities;
c. Correspondence between types, hierarchy, and material content;
d. Can be implemented;
e. Usability and expedience;
f. Clarity of formulation; and
g. Openness. ${ }^{3}$

Some of the principles in the Act No. 21 of 2008 and its provisions are not only against each other, as in Article 55 paragraph (1) and Article 55 paragraph (2), but also contrary to the Act No. 50 of 2009 that unequivocally determine the absolute authority of Religious Judicature in resolving Islamic Banking disputes.

\section{C.1.2. Research Approach.}

This study uses several approaches such as Statutory Approach. This approach is emphasized by analyzing a number of regulations, such as Act Number 21 of 2008 on Islamic Banking, Act Number 48 of 2009 on Judicial Power, and Act Number 50 of 2009 on the Second Amendment to Act Number 7 of 1989 on the Religious Judicature.

Based on the statutory approach, the basis and source of law governing Islamic Banking disputes will be focused on the methods or way of Islamic Banking dispute settlement through litigation.

The importance of the statutory approach was also recognized by Peter Mahmud Marzuki. He argued that legal research on the level of dogmatic legal research or research for the purpose of legal practice cannot be separated from the approach of the legislation. ${ }^{4}$ According to Sudikno Mertokusumo, dogmatic law is the branch of science that studies the positive law (written and unwritten law) and the settlement or solution of legal problems (yuridprudensi). His approach is always associated with positive law. ${ }^{5}$

\section{Discussion.}

The authority of Religious Judicature related to Islamic Banking dispute is authorized under litigation and became an important discussion point. The source of this authority is from the explanation of Article 49 of Act No. 3 of 2006 jo. Act Number 50 of 2009 on Religious Judicature, and is an absolute competence.

Different from Act No. 21 of 2008 on Islamic Banking, which in Article 53 which its paragraphs contradict each other, Article 55 paragraph (1) of Act No. 21 of 2008 explicitly set the absolute authority of the Religious Judicature in Islamic Banking dispute settlement, however, the next paragraph actually opens the opportunity to settle the dispute outside the Religious Judicature.

The Constitutional Court Decision No. 93 / PUU-X / 2012 is a legal provision that returns the absolute authority of the Religious Court in resolving Islamic Banking disputes. However, the Constitutional Court decision according to Eddie Hudiata, ${ }^{6}$ also raises the problem of the new law such as lack of legal certainty for the parties that will settle the Islamic Banking disputes through non-litigation ways.

The author disagree with Edi Hudiata, the Act No. 48 of 2009 on Judicial Power, determined that the attempts

\footnotetext{
${ }^{1}$ See Act No. 50 of 2009 on the Second Amendment to Law No. 7 of 1989 on the Religious Courts (Article 1 paragraph 2)

${ }^{2}$ Soerjono Soekanto, Pengantar Penelitian Hukum, UI Press, Jakarta, 1986, p. 12

${ }^{3}$ See Law No. 12 of 2011 on the Establishment Regulation Legislation (Article 5)

${ }^{4}$ Peter Mahmud Marzuki, Penelitian Hukum, Kencana, Jakarta, 2010, p. 96

${ }^{5}$ Sudikno Mertokusumo, Teori Hukum, op cit, p. 39

${ }^{6}$ Edi Hudiata, Penyelesaian Sengketa Perbankan Syariah Pasca Putusan MK Nomor 93/PUU-X/2012: Litigasi dan Non Litigasi, UII Press,

Yogyakarta, 2015, p. 98
} 
to settle civil disputes can be performed outside the state court through arbitration or alternative dispute settlement (Article 58) because Islamic Banking is a part of the law civil and civil cases, hence, the settlement of disputes through non-litigation becomes an integral part and is closely related to other forms of dispute settlement law.

The legal relationship between the customers and the Islamic Bank is not always gone smoothly or seamlessly, for sometimes one even both sides do not meet the legal obligation. Furthermore, there are several sources of disputes in Islamic Banking, for instance (1) Default (break a promise), (2) Torts (Onrechtsmatige Daad); and (3) Problems due to circumstances beyond human will (overmacht/forje majeure). ${ }^{1}$

Default or break a promise is defined as a situation in which the debtor does not fulfill or meet his promise and all of it can be blamed. ${ }^{2}$ Fuady Munir explained that the definition of the performance of a contract is the implementation of the matters that have been agreed or written in an agreement by both parties who are committed to it. While the default is contrary to the performance. In this case, the performance, the content of the agreement is executed or complied with by the parties in performance, then the default does not run or meet the contents of the agreement. ${ }^{3}$

In the practice of Islamic Banking, a customer financing is considered in default if $\mathrm{s} / \mathrm{he}$ does not perform or late to perform the obligation or perform but not as had been agreed in the financing agreement. Generally, the default must be declared beforehand formally in a default statement, by warning (subpoena) the party which fails to perform its obligations. For the financing agreement, basically, the default state can immediately be met even without warning or default statement in advance of the bank, because the circumstances of the default have been evident by over time fulfillment of payment.

Law Compilation of Islamic Economics, determine default, named as broken promises in Article 36 that "Parties may be perceived to default when iniquity:

a. Not doing what is promised to do;

b. Implements what was promised, but not as promised;

c. Do what was promised, but it was too late; or

d. Doing something that should not be done based on the agreement. "

The author who conducted a research of the provisions of default in Article 36 of Law Compilation of Islamic Economics, was influenced by the provisions of the Code. According to Djaja S. Meliala, ${ }^{4}$ there are four default states in civil, as follows:

1. Do not meet performance;

2. Late for a performance;

3. Meet performance improperly;

4. Doing something that should not be done according to the agreement.

According to Dewi Nurul Musjtari, ${ }^{5}$ Mudharabah financing is the Islamic bank as the owner of the funds (shahibul maal) cooperation with the customer (mudharib) who have the expertise to manage the business productive and lawful and the sharing of profits from the business that is related to the agreed ratio, usually the forms of default made by customers in mudharabah financing can be:

1. Financing recipient uses beyond its original purpose, as mentioned in the financing agreement;

2. Financing recipients do not pay the number of financing obligations in accordance with provisions in the financing agreement or any other amounts of payment under the financing contract or other documents made under the Financing Agreement;

3. Financial reports that are submitted to the bank is untrue;

4. Financing recipients fail to perform or do not perform the requirements and other provisions in the Financing Agreement (or an addition, alteration, renewal or replacement) and or the occurrence of violations or omission according to the terms stated in the collateral agreement that was made related to the Financing Agreement;

5. Financing recipients transferred business in anyways, including a merger, consolidation or acquisition by another party;

6. The entire estate of the customer is confiscated by the government or the Court;

7. Permits or approvals granted or issued by the competent authority on customers revoked or declared invalid so that customers do not have the right to build or complete the construction or carrying out the project;

Default on banking and Islamic Banking, in particular, is one of the facts that are found, because the customer in default of the Financing Agreement for some things or certain factors, for instance, the business that is financed by Islamic Bank is difficult to develop or because of the inability of customers.

Furthermore, Tort (Onrechmatige Daad) in the Article 1365 of Civil Code, states that "A party who commits

\footnotetext{
${ }^{1}$ Dewi Nurul Musjtari, Penyelesaian Sengketa Dalam Praktik Perbankan Syariah, Parama Publishing, Yogyakarta, 2012, p. 144-149

${ }^{2}$ M.Marwan and Jimmy P, Op Cit, p. 643

${ }^{3}$ Munir Fuady, Konsep Hukum Perdata, op cit, p. 207

${ }^{4}$ Djaja S. Meliala, Op Cit, p. 99-100

${ }^{5}$ Dewi Nurul Musjtari, Op Cit, p. 145-146
} 
an illegal act which causes damage to another party shall be obliged to compensate therefor." ${ }^{1}$ According to Abdulkadir Muhammad, the formulation is a tort if it meets the following four elements:

a) The act should be against the law (onrechmatige);

b) The act should result in losses;

c) The act should be done with an error (default);

d) There must be a causal relationship Between acts and damages. ${ }^{2}$

Dewi Nurul Musjrati explained the torts both by the Islamic Bank customer and Islamic Bank, that:

1. For customers:

a) Customers fled after the withdrawal of financing;

b) Falsifying signatures, official letters, and accounting records;

c) Using capital partially or in whole, or part of the results of the business that should be the right of banks;

d) Customer business affects the environmental pollution due to non-fulfillment of the provisions of Environmental Impact Analysis.

2. For Islamic Banks:

a) to achieve the set targets, in providing financing to customers, banks will no longer consider the ability to channel the finance, both in terms of micro-economic and human resources as finance manager. Thus, it shows the bank did not pay attention to the principles of prudential banking practice or prudential banking principle as set in the Banking Law and Regulation of Bank Indonesia.

b) The graft from the customer to the human resources of banks occasionally happens in financing application approval process;

c) The mistake in assessing the collateral (not based on price or fair value). ${ }^{3}$

Torts is essentially an act that is clearly against or violation of applicable law, moreover, Default is essentially events or circumstances that occur as a result of non-fulfillment of an agreement or contract of banking, in this case, is Islamic Banking.

The next is problems that are as a result of circumstances beyond human will (coercion / forje majeure), such as the customer's business is destroyed by floods and landslides, or the burning of places and projects financed by Islamic Banking. The problems often occur, including caused by an earthquake.

The disputes between customers and the Islamic Bank generally occurs because one of the parties objected and harmed by others, therefore a written agreement contained in a contract has been accomplished. Customers who deposit their funds in Islamic Bank, of course, can pursue a lawsuit based on banking institutions that are in default, if they may not withdraw or take the savings, for example, if the savings are stolen by bank employees.

The settlement of the Islamic Bank financing problems, according to Dewi Nurul Musjtari, has some legal aspects: ${ }^{4}$

a) Restructuring of Financing and the need for legal action;

b) Analysis of the legal status of the debtor/guarantor and its business;

c) Analysis of the legal status of the assets held by the debtor to financing restructure;

d) offering later, Agreements and documents in order to financing restructure;

e) Recovery in the context of the settlement of financing;

f) Litigation and lawsuits, execution of guarantees, emptying and criminal charges;

g) The takeover of collateral and reselling.

Based on the discussion about the legal aspects of such treatment, the completion of the financing problems at Islamic Bank will be settled by litigation process, and the process is the main research of discussion because it is closely linked to the substance of the law duties and authorities of the Religious Court in resolving disputes.

In fact, the settlement of Islamic banking dispute, which is filed in the Religious Court still decides to use the approach of the old regulation, although the dispute occurred after the Constitutional Court's verdict number 93 / PUU-X / 2012 which claimed the absolute authority of Religious Court to resolve the dispute of Islamic Economics. It can be seen in the decision of Surabaya Religious Court in the verdict numbers: 5718 / Pdt.G / 2014 / PA. Sby that states that the Religious Court (in-casu, Surabaya Religious Court) has no authority to investigate and adjudicate Case Number: 5718 / Pdt.G / 2014 / PA. Sby on November 24 ${ }^{\text {th }}, 2014$, filed by the litigants, the Bank's customers, in agreement letter has been mentioned that a dispute between the customer and the Bank will be resolved through Basyarnas (National Sharia Arbitration Board) so that the Religious Court has no authority to try the case. The consideration of the judge in this decision is an agreement that has been carried out around 2011

${ }^{1}$ R. and R. Tjitrosudibio Subekti, Kitab Undang-Undang Hukum Perdata, Op Cit, p. 346

${ }^{2}$ Abdulkadir Muhammad, Hukum Perikatan, Citra Aditya Bakti, Bandung, 1990, p. 142

${ }^{3}$ Dewi Nurul Musjtari, Op Cit, p. 148-149

${ }^{4}$ Dewi Nurul Musjtari, Penyelesaian Sengketa Akad Pembiayaan dengan Jaminan Hak Tanggungan dalam Praktik Perbankan Syariah Parama Publishing, Yogyakarta, 2016, p. 178 
before the Constitutional Court decision number 93 / PUU-X / 2012 which claimed the absolute authority of Religious Judicature to settle the disputes of Islamic Economics. Thus, the judge accepts the proposed exception stating that the Islamic Court has no authority to try the case. However, the researcher argued, after the Constitutional Court decision No. 93 / PUU-X / 2012, the Islamic banking dispute settlement conducted through Religious Judicature, the litigation settlement in accordance with the absolute authority of the Religious Judicature. Dewi Nurul Musjtari collected procedures and dispute settlement processes of Islamic economics, especially Islamic Banking in Religious Court, as follows: ${ }^{1}$

Islamic economic dispute is a dispute of default/violation of the points that have been agreed on in the agreement, for example:

a. The default of bank to refund customer deposits, in the wadi'ah agreement;

b. Bank reduces customers benefit ratio without their agreement; in the Mudharabah agreement;

c. Customers conduct the business of liquor from the loan of Islamic banks; in Qardh agreement.

Religious Court authorizes the convict of customers or bank in default which causes real loss; if there is a demand for compensation due to the default:

a. The default is from an agreement between the parties (Article 1320 of Civil Code) and the agreement is based on the will or an agreement;

To be cited as a default must have default statement (ingebreke Stelling) as referred to in Article 1243 of Civil Code;

b. Torts - lawsuit contains claims for compensation simply which is from a tort or default.

\section{E. Closing}

\section{E.1. Conclusion.}

Based on the discussion above, it is concluded that:

1. Religious Judicature as one of the country's judiciary has the right and constitutional basis in Indonesia which has been known before the Dutch East Indies. Duties and powers of the Religious Judicature increasingly expanded up in the field of Islamic economics, especially in Islamic banking.

2. Islamic banking as part of Islamic economic faced a number of challenges, such as the dispute settlement mechanism. The vagueness of the law towards the articles on the dispute settlement procedure of Islamic Banking, especially regarding the authority in trying the case in the Religious Judicature or in the District Court.

\section{E.2. Suggestion}

1. The assertion for every activity of Islamic Banking in the agreement with customers, especially for dispute settlement to be completed by the Religious Court for its authority has been strengthened by a Constitutional Court decision number 93 / PUU-X / 2012.

2. The need for the drafting of new Religious Judicature in lieu of procedural law based HIR / RBg, as well as harmonization and synchronization of the legislation.

\section{Bibliography}

Adolf Huala, Hukum Penyelesaian Sengketa Penanaman Modal, Kani Media, Bandung, 2011.

Arto Mukti H.A., Pembaruan Hukum Islam Melalui Putusan Hakim, Pustaka Pelajar, Yogyakarta, 2015.

Black Henry Campbell, Black’s Law Dictionary, West Publishing Co, St. Paul, 1979.

Fuady Munir, Konsep Hukum Perdata, RajaGrafindo Persada, Jakarta, 2015.

Hadjon Philipus M., Pengantar Hukum Administrasi Indonesia, Gadjah Mada University Press, Yogyakarta, 1993.

Hudiata Edi, Penyelesaian Sengketa Perbankan Syariah Pasca Putusan MK Nomor 93/PUU-X/2012: Litigasi dan Non-Litigasi, UII Press, Yogyakarta, 2015.

Manan Abdul, Penerapan Hukum Acara Perdata di Lingkungan Peradilan Agama, Kencana, Jakarta, 2005.

Margono Suyud, ADR \& Arbitrase-Proses Pelembagaan dan Aspek Hukum, Ghalia Indonesia, Bogor, 2000.

Marwan M. dan Jimmy P, Kamus Hukum, Reality Publisher, Surabaya, 2009.

Marzuki Peter Mahmud, Penelitian Hukum, Kencana, Jakarta, 2010.

Meliala Djaja S., Perkembangan Hukum Perdata Tentang Benda dan Hukum Perikatan, Nuansa Aulia, Bandung, 2008.

Mertokusumo Sudikno, Teori Hukum, Universitas Atmajaya, Yogyakarta, 2011

, Mengenal Hukum. Suatu Pengantar, Liberty, Yogyakarta, 2005.

Minarno Nur Basuki, Penyalahgunaan wewenang Dalam Pengelolaan Keuangan Daerah Yang Berimplikasi Tindak Pidana Korupsi, LaksBang Mediatama, Yogyakarta, 2011.

Muhamad Abdulkadir, Hukum Perikatan, Citra Aditya Bakti, Bandung, 1990.

${ }^{1}$ Dewi Nurul Musjtari, Ibid, p. 232-236 
Muhammad Takdir, Mediasi. Penyelesaian Sengketa Melalui Pendekatan Mufakat, RajaGrafindo Persada, Jakarta, 2011.

Musjtari Dewi Nurul, Penyelesaian Sengketa Akad Pembiayaan dengan Jaminan Hak Tanggungan dalam Praktik Perbankan Syariah, Parama Publishing, Yogyakarta, 2016.

Musjtari Dewi Nurul, Penyelesaian Sengketa Dalam Praktik Perbankan Syariah, Parama Publishing, Yogyakarta, 2012.

Pruitt Dean G. dan Jeffrey Z. Rubin, Konflik Sosial, Pustaka Pelajar, Yogyakarta, 2004.

Ridwan HR, Hukum Administrasi Negara, RajaGrafindo Persada, Jakarta, 2006.

Ridwan Juniarso dan Achmad Sodik Sudrajat, Hukum Administrasi Negara dan Kebijakan Pelayanan Publik, Nuansa, Bandung, 2010.

Rudyat Charlie, Kamus Hukum, Tanpa Penerbit, Tanpa Tahun.

Salim HS, Perkembangan Hukum Kontrak Di Luar KUH. Perdata, RajaGrafindo Persada, Jakarta, 2006.

Salim HS dan Erlies Septiana Nurbani, Penerapan Teori Hukum Pada Penelitian Tesis dan Disertasi, Buku Kesatu, RajaGrafindo Persada, Jakarta, 2014

Subekti R. dan R. Tjitrosudibio, Kitab Undang-Undang Hukum Perdata, Pradnya Paramita, Jakarta, 2002.

Soekanto Soerjono, Pengantar Penelitian Hukum, UI Press, Jakarta, 1986.

Usman Rachmadi, Pilihan Penyelesaian Sengketa di Luar Pengadilan, Citra Aditya Bakti, Bandung, 2013.

\section{Legislation}

Constitution of the Republic of Indonesia Year 1945.

Act No. 12 of 2011 on the Establishment Regulation Legislation.

Act No. 48 of 2009 regarding Judicial Power

Act No. 49 of 2009 regarding the Second Amendment to Law No. 2 of 1986 concerning the General Court Act No. 50 of 2009 regarding the Second Amendment to Law No. 7 of 1989 on the Religious Judicature Act No. 10 of 1998 on the Amendment of Law Number 7 of 1992 concerning Banking

Act No. 21 of 2008 concerning Sharia Banking

Act No. 7 of 1992 concerning Banking

\section{Regulations}

Government Regulation No. 9 of 1975 on the implementation of Law No. 1 of 1974 on Marriage

Government Regulation No. 72 of 1992 on Bank Based on Principles of Sharing

SEMA No. 08 of 2008 on Sharia Arbitration Decision Execution

SEMA No. 08 of 2010 on the assertion Not Applicability of SEMA No. 08 of 2008 on Sharia Arbitration Decision Execution 